\title{
THE HERMENEUTICAL DIMENSION OF THE BIOETHICAL ENTERPRISE. NOTES ON THE DIALOGICAL/NARRATIVE FOUNDATIONS OF BIOETHICS
}

\author{
Fernando Lolas Stepke²
}

\begin{abstract}
Based on the challenges posed by the scientific activity of the author, related to the integration and harmonization of heterogeneous discourses, a hermeneutic framework for bioethics is stressed. It is mainly concerned with elucidating intentions, hidden meanings, and motivations of texts and behaviors that can be converted into texts. Equating the mimetic circle of Paul Ricoeur with the hermeneutical circle is advocated as a practical application. The importance of the hermeneutic approach suggests that it can also be applied to written productions in bioethics, since the history of this intellectual endeavor can be reformulated considering a reinterpretation of its record.
\end{abstract}

Key words: hermeneutics, bioethics, mimetic circle

La dimensión hermenéutica de la empresa bioética. Notas sobre el fundamento dialógico/narrativo de la bioética

Resumen: Basándose en los desafíos de su propia trayectoria científica, relacionados con la integración y la armonización de discursos heterogéneos, se destaca el marco de referencia hermenéutico para la bioética. Se relaciona con dilucidar intenciones, significados ocultos y motivaciones de textos y conductas que pueden ser convertidas a textos. Equiparar el círculo mimético de Paul Ricoeur con el círculo hermenéutico se propone como una aplicación práctica. La importancia de la aproximación hermenéutica sugiere que también puede aplicarse a las producciones escritas de la bioética, ya que la historia de esta disciplina puede reformularse considerando una reinterpretación de su registro

Palabras clave: hermenéutica, bioética, círculo mimético

A dimensão hermenêutica da empresa bioética. Notas sobre a narrativa dialógica dos fundamentos da bioética

Resumo: Baseado nos desafios decorrentes da atividade científica do autor, relacionados à integração e harmonização dos discursos heterogêneos, quadro hermenêutico para a Bioética é traçado. E sua preocupação central está em elucidar intençóes, significados ocultos, motivaçóes dos textos e comportamentos que podem ser convertidos em textos. Igualar o círculo mimético de Paul Ricoeur com o círculo hermenêutico é defendida como uma aplicaçáo prática. A importância da abordagem hermenêutica sugere que pode também ser aplicada às produçóes escritas em Bioética, desde que a história deste empreendimento intelectual pode ser reformulada considerando uma reinterpretaçáo de seu registro.

Palavras-chave: hermenêutica, Bioética, círculo mimético

\footnotetext{
${ }^{1}$ Abridged version of a conference delivered at the 17th Losinj Days of Bioethics, Mali Losinj, Croatia, May 20th, 2018, after receiving the "Fritz Jahr Award" in Bioethics from the universities of Rijeka and Zagreb. Fort he purpose of this publication, the bibliographic references have been reduced to the essential.

${ }^{2}$ Interdisciplinary Center for Studies in Bioethics, University of Chile, Chile.

Correspondence: flolas@uchile.cl
} 


\section{Introduction}

The main problem I have confronted in my scientific work is the harmonization and integration of different discourses and the need to "translate" constructs from one "epistemic culture" (Wissenskultur)(1), or rationality, to another.

My early work sought to find correlates between three dimensions of what I called "The psychophysiological triad"(2).

In the human sciences, we have three forms of producing facts: methods for observing and quantifying overt behavior, methods for analyzing and depicting physiological markers and methods for tackling mentation and affect in language. The expectation that constructs from one of these methodical texts find a correlate or replication in the others - a belief still present in psychiatry and psychosomatics - is contradicted by reality. You may anticipate physiological findings observing behavior. But their relationship goes beyond the idea of a "correlate" of emotions and mentation in physiology or overt behavior. It is a challenge.

Our methodical solution was to assume that each "text" is a "context" for the others: data from one domain can be understood using concepts from the others. But real conceptual integration lies beyond each independent language. Each "text"- physiology, behavior, language-, has its own development, rhetoric, and social practice. The challenge is the construction of a meaningful "metatext".

To take an example. The word emotion is not only a physiological change. Not only a verbal expression. Not only a behavioral manifestation. Emotions are syndromes constituted by these three components taken jointly. An observer may select one of these descriptive languages to label an emotion but each of them has validity in its own right and the causalities evinced in one domain are not necessarily found in the others. They are forms of description that cannot replace each other. They complement each other.

A fourth axis must be added to this descriptive and heuristic complex of methodologies and langua- ges: time. Not only cosmological time but, more importantly, biographical subjective time. I hoped to complement the "crossed comprehension" between scientific languages (or texts), adding the biographical dimension through the concept of narrative: interrelating languages, complementing their causal chains, and supplying "arguments", events, and characters.

Each method-based language creates its own realities. Physiology and genetics never produce correlates for the concepts employed in descriptive psychopathology. A "biopsychosocial model" is a juxtaposition of languages and texts based on causal rationalities difficult to integrate within the expertise of a single practitioner. The community of practice in medicine is built upon many scientific rationalities and languages but demands an integration not found in any one of them(3). This integration occurs in the domain of personal experience.

Our method for studying language in the psychophysiological triad was content analysis, a technique to uncover hidden or latent meaning in texts. It is a form of semantics linking the manifest content of speech to psychological categories like anxiety, hostility, hope, and others through empirical rules (frequency, the centrality of expression to construct, etc.,.)

This brief depiction of my scientific endeavors indicates the importance of a hermeneutic or interpretive attitude incorporated (albeit unconsciously) in my scientific practice. The problem of translating between different methodical domains, each with its own language and texts, was essential, permanent, and insoluble.

\section{From the intra personal to the interpersonal} space

If we move from the "intrapersonal" sphere to the social field and observe the diverse approaches to the same problems taken by "moral" and "epistemic" strangers, we find similar difficulties. More complex, perhaps, requiring the need to understand the different, to comprehend, and to interpret words and deeds. Bioethics today is faced with major challenges, the same we faced when defining an emotion. We have to translate 
and integrate discourses and languages. Ethics, as a linguistic justification of actions, is formulated from different perspectives. No one of them in isolation results in deep and wide comprehension or acceptance. We are faced with different worldviews, expectations, influences, languages, each striving at dominance and full legitimacy.

The limitations of epistemic or moral cultures appear when we try to integrate them. They are unable to express other sensitivities. They are caught in methods, when we need an art of integration, a modus of approaching realities in order to comprehend, interpret, and integrate. This is the reason why I came to consider a hermeneutic approach to bioethical challenges as a possible solution to our need for understanding and making decisions. Bioethics is a polyphony with many voices.

My aim is to explore hermeneutical thinking as an alternative to the "technomorphic" orientation of the bioethical discourse, in view of the predominance of the principialist version popularized by the American "neo-bioethical" movement. Bioethics, as psychoanalysis, was born in Europe but became global after its adoption by the North American intellectual establishment. The so-called "Georgetown mantra" and its four grounding principles, while providing ways of formulating moral conflicts, does not contribute to enhance moral consciousness or facilitate deliberation and reflection. Systematic "principialism" in bioethics helps in decision-making but hardly produces new insights or develops moral imagination. It replicates technical procedures found in scientific disciplines.

As a staff member of the Pan American Health Organization (Regional Office of the World Health Organization), I helped to establish bioethics in the Americas and the Caribbean. My task was in the health sector but involved ecological and organizational issues in public policies. I defined bioethics as "the use of dialogue for formulating and resolving dilemmas posed by the application of science and technology to human affairs". During my office term between 1998 and 2010 and also as a member of the UNESCO International Bioethics Committee I realized that the problem is not the establishment of an academic discipline but the construction of dialogical spaces where diverse perspectives can be examined. Dilemmas are problems whose solution pose other problems; some of these are never solved but need to be "dissolved" in common aspirations, good life and the flourishing of persons with different cultural backgrounds, expectations, and resources. We had to accept that people may differ profoundly not only in what they consider real problems but in their justification for moral actions.

Ethics is to moral what musicology is to music. It is the rational and reasonable foundation and justification of practices found in custom and tradition. I stress these two adjectives: rational and reasonable. Logical syllogisms and arguments do not solve the challenges of life. Another approach is needed, expressed by the word reasonable. The linguistic turn demands that justification of practices and rules is understood and accepted by all those concerned. This link to language is reflected in the profound relationship of moral deliberation to narrations. Narratives always have been present in moral thinking as stories, parables, fables, and texts of various kinds. Participants in dialogues bring ideas, prejudices, and the linguistic tradition of their communities. In multicultural societies, we should better speak of "multilogues" because participants and stakeholders are multiple and diverse. They may have conflicting views on essential issues.

Values are "universals of meaning" that justify actions. Some are instrumental, means to achieve goals; others are essential: ends in themselves, such as dignity and autonomy. These values should be respected in their own right, not because they lead to better or more efficient action. The confusion arises when what is technically feasible is identified with what is morally justified. It is necessary to distinguish between the technical foundation and the ethical justification. Many quandaries of contemporary science derive from this confusion. Not everything that can be done should be done. Philo-tekhnia is not the same as Philo-anthropia, even in those professions that define themselves as service to people. The dehumanization of technoscientific medicine was responsible for abuses in the past. 
People may agree on what actions are needed in a given case but differ greatly on the reasons or justification for their choices. Many philosophical confrontations derive from ethical thinking of a "monological" nature. A thinker may derive axioms and rules from his/her general theories without considering the procedural/dialogical/ narrative nature of the bioethical enterprise. This relies upon a "conversation" or dialogue between different voices. To be satisfactory, this dialogue must consider the fact that different people, facing the same demands, may reach different conclusions.

In dialogical ethics, a common ground is essential.

This common ground is language. Language is not a product of human interaction but a productive force shaping common life. "Linguisticality" (Sprachlichkeit) and speech games are fundamental to understand the world of life (Lebenswelt) for different agents and actors. This contribution of Wittgenstein, the relation between speech games and life forms, is important for the dialogical-narrative foundation of bioethics in a hermeneutic attitude.

\section{The hermeneutical perspective}

Hermeneutics has different meanings in the history of thought. It originated in the need to understand the true meaning of written texts in religion and law. Textauslegung provides indications for the correct understanding of texts. The intention and feelings of those who produced them may be ascertained. In Schleiermacher's version of hermeneutics, the aim was to avoid or diminish misunderstanding. For Dilthey, it represented the canon for all Geisteswissenschaften. These disciplines differ from the natural sciences. The explanation is complemented with comprehension and interpretation. Human actions cannot be explained in causal terms only. They need to be understood considering aims and motivations. Max Weber's notion of Handlung was action with meaning in a social context. The application of Jaspers to psychiatric praxis distinguished Erklären and Verstehen as two moments of the art (or modus) of the human encounter, beyond the application of empirical methods (methodus) $(4,5)$.
Several meanings of hermeneutics can be discerned: 1) a theory of biblical exegesis; 2) general philosophical methodology; 3) science of all linguistic understanding; 4) methodological foundation of Geisteswissenschaften; 5) phenomenology of existence and existential understanding; 6) systems of interpretation useful in the analysis of juridical and literary texts.

Two trends can be discerned: the methodological and the ontological. Emilio Betti criticizes Gadamer and Heidegger for interrupting the Diltheyan tradition, fundamental for the consolidation of history. He demands a universal methodology instead of an existential factum and distinguishes Auslegung (description) from Sinngebung (understanding), a distinction in line with Hirsch's distinction between meaning and significance when approaching the study of texts and myths, applicable to any cultural object.

Both aspects of the hermeneutical tradition are useful a sound bioethical discourse if hermeneutics is conceived also as "removal of hindrances" to understanding. This removal of hindrances is essential for building trust and tolerance among different stakeholders in any social activity.

In bioethics, we do not deal only with written texts. We observe behaviors. To understand them, they have to be "textified", converted into logos. In Gadamer's expression, only being that is verbalized is true being. When expressed in language, actions and intentions are understood and interpreted. This conversion to an open, accessible medium, represents the basic "linguisticality" of the hermeneutical attitude. The solipsistic tradition of the cogito assumes that we imagine or assume the inner world of others intuitively. Linguistic constructions are necessary for a hermeneutical dialogue. The human social environment is not simply Umwelt, as in animals, it is Lebenswelt constructed by language. It is circum-stare, circumstance, in the words of the Spanish philosopher Ortega y Gasset. It has meaning embedded in the linguistic construction of sentient humans. Understanding others demands interpreting their actions and motives.

There are two levels in this approach. The semantics of moral action, the link between signs and 
their meaning "from the outside". Hermeneutics goes a step further, it is the "inner" appropriation and comprehension of what is perceived, making it a part of our experience.

Hermeneutics is not only a procedure for comprehending and interpreting. It is also an ontological dimension of the Dasein, in Heidegger terms(4). Search for meaning is essential for Being-in-theworld. The truth of human existence is beyond an array of methods for explicating or causally explaining human behavior and thinking. It is Aletheia, uncovering of possibilities in the existential world. Understanding others, we are also subjects of self-presentation. Entering a dialogue with others reveals who we are and what we want.

This aspect of the hermeneutical attitude demands what Gadamer has stressed. Instead of eliminating all influences from our personal and social background we need a dialogue with our own traditions and linguistic habits. Prejudices are not necessarily hindrances to understanding. They are part of our identity. We always belong to a tradition and unconsciously respect it. Instead of suppressing our past we should master its influence, be aware of it, and make it productive for the never-ending process of comprehending others in their deeds, words, and texts.

Some methodical implications are relevant for the bioethical enterprise. The contribution of Paul Ricoeur and his insights into narrativity are found in his ideas on the "mimetic circle" (6).

Confrontation with moral problems resembles the construction of narratives. First, in Mimesis $I$, there is an anticipation based on assumptions, hidden beliefs, and expectations. This is pre-figuration. Then the process of configuration of the story unfolds (Mimesis II). Characters, events, processes are developed. The story has a beginning, a course, and an end. It may refer to real events or be a game of the imagination. It may appeal to truth or to verisimilitude and coherence (history versus fiction). It structures narrative time, between cosmological and subjective times. When the narration is completed, its effect derives from a re-figuration by the "reader" or interpreter (Mimesis III). The efficacy of narratives depends on this final stage. It is a stadium in which a fusion of horizons (Horizontverschmelzung) occurs. The subject addressed by the texts incorporates the narration and creates a new reality, based on his/her own preconceptions and the narrative experience. This newly formed reality creates a different Erfahrungsraum (Kosselleck), which in turn opens a new Erwartungshorizont. The hermeneutic experience can start again, from a different basis and with a wider base. The circle has been closed.

This "mimetic circle" can be incorporated into bioethical practices. It makes obvious what we do. Formulating a bioethical problem or challenge, we start with our prejudices and preconceptions. Then a story is created. The resulting text is a product that can be evaluated, transformed, accepted or rejected.

Bioethics is a social process, a technical procedu$r e$, and a social product. (The three "Ps" of Jürgen Habermas)(7). As a product, it enters into the social imaginary and invites further inquiry. In the quest for truth, coherence, verisimilitude, and usefulness, the mimetic circle is a hermeneutical circle.

In the tradition of hermeneutics, as Gadamer remembers, we find the notion of Subtilitas. Subtilitas intelligendi, subtillitas explanandi, subtilllitas applicandi. More than to a method, this word refers to a sensibility close to aesthetical experience, a form of knowledge free of rules and norms but not arbitrary. Gadamer and other hermeneuticists rely on aesthetics to support their proposals. Ars bene legendi and ars bene dicendi are complemented with a good form of acting

The term "applied" in bioethics does not mean "downward" application of theoretical reflection. Incorporated in the hermeneutic attitude, the application is essential for comprehension and interpretation. Interpreting, we "place" the conclusion in real life. The experience becomes meaningful in the Lebenswelt.

The stages of the mimetic circle resemble the three aspects of Subtilitas. Applied to bioethical deliberation and analysis, they are a methodological tool. The main challenge nowadays is mutual understanding. Different languages create diffe- 
rent worlds. Different traditions lead to different expectations. Everywhere we are faced with heterogeneity, contrast, and incomprehension. Different rationalities, contrasting discourses, competing social interests make common life difficult. Already in the Rijeka Declaration of 2011 the need to cross boundaries was spelled out as a directive for the future.

Hermeneutical Bioethics is a global paradigm for overcoming the fragmented view of the world. There are not only two cultures, as C.P. Snow proposed; many more. The future should include subtilitas intelligendi (explanation), subtillitas explanandi (comprehension) and subtilitas applicandi (interpretation), all three. Bioethical discourse cannot ignore scientific experience. But it should also comprehend and understand and, finally, it should interpret.

Comprehension and interpretation, closely related, should be distinguished. Interpretation cannot be reduced to comprehension. It situates comprehension in the wider landscape of human life. It "positions" the conclusions of explanation and comprehension within practical endeavors. In theology, the hermeneutics of sacred texts is not only demythologization of the Scriptures or reaffirmation of the faith. It is preaching, the opening of meaning to others. In juridical hermeneutics, the true sense of the word in laws and regulations, its formative stages and its comparison in different contexts is what matters. This is application in a strict sense.

Bioethics, in this perspective, is a general, global enterprise, aiming at deconstructing and reconstructing ideologies, beliefs, and expectations by interpreting words, deeds, and texts. This challenge is a program of inquiry: to explore the meaning of words and assertions from different angles and considering fluctuations of concepts over time and situation. For example, the word "life" can be understood in different forms. It may be biological life, the life of the universal spirit of creation, or a transcendent momentum of existence. To respect life may mean different things to different people. Deconstruction and reconstruction of meaning is part of the hermeneutical work, always a conversation, a dialogue, that leads to narrations.
Bioethics as conversation (dialogue, multilogue) is rooted in what my teacher in Heidelberg, Paul Christian, termed "bipersonality" (8). The conversation can be between two persons. It can also exist between a person and texts, between behaviors and experiences, between what Dilthey called Erlebnisse, living experiences. In the dialogue, the identities of those who interact are dissolved temporarily, affirming the realities they address. People of good will, comprehending and interpreting, may reach the elusive virtue of tolerance. They may understand that differences in context and outlook not necessarily mean fighting each other. The aim is to construct a common universe "dissolving" the differences, resolving conflicts, and applying knowledge and wisdom to human affairs respecting custom, tradition, and belief.

It is a language game, but a serious one.

\section{A brief note on history and its interpretation}

Why and when do we consider that an event has historical importance?

When that event can be placed in the context of a valoric tradition. The battle of Lepanto is history of Western Europe because it can be interpreted (positioned) in a constellation of values, Western values. May not have any relevance in China or India.

The same happens with Jahr's contribution to bioethics. Despite its scant influence on further developments, when we look at it it may be interpreted in the context of European cultural tradition. It thus has historical importance. Even if the direct impact was negligible in terms of citations and references, the historical value, now important for our understanding of the field, is considerable. As we know, written history is a permanent reconstruction of the past. Bioethical past is now different from what is was before the discovery of Jahr's contribution and its future is not what it used to be.

The hermeneutic attitude can also be applied to the texts produced in science and bioethics. Their analysis provides clues to the hidden meanings and intentions of those who produce the texts. It also uncovers the contexts in which written 
contributions can be framed. Despite its weaknesses, when viewed in this perspective, Kuhn's notion of paradigm can be reinterpreted not only as an important contribution but also as a form of communication characteristic of a discipline at a given stage of its development.

\section{References}

1. Knorr-Cetina K. Wissenskulturen. Ein Vergleich naturwissenschaftlicher Wissensformen. Frankfurt a.M.:Suhrkamp; 2002.

2. Lolas F. Psicofisiología de la Personalidad. Santiago de Chile: Facultad de Ciencias Sociales/Bravo y Allende; 1998.

3. Lolas F. L'éventail des pratiques en psychiatrie: intégration des processus complémentaires de narration. L'Evolution Psychiatrique 2017; 82(2): 18-23.

4. Gadamer H-G. Wahrheit und Methode Tübingen: J.C.B. Mohr (Paul Siebeck); 1975.

5. Jaspers K. Allgemeine Psychopathologie 6. Auflage. Berlin, Heidelberg: Springer; 1953.

6. Ricoeur P. Temps et récit. Paris: Editions du Seuil; 1985.

7. Habermas J. Theorie des kommunikativen Handelns. Frankfurt a.M.: Suhrkamp; 1988.

8. Christian P. Wesen und Formen der Bipersonalität. Stuttgart: Enke; 1949. (Trad. Española F. Lolas, Esencia y Formas de la Bipersonalidad, Monografías Acta Bioethica N¹, Santiago de Chile, 2009).

Received: June 19, 2018

Accepted: July 28, 2018 